\title{
MENIMBANG METODE SYAIKH ABDUL QADIR AL-JILANI DALAM MEMAHAMI SIFAT-SIFAT ALLAH
}

\author{
A6dul Hakim \\ Fakultas Sains dan Teknologi UIN Maulana Malik Ibrahim Malang \\ Jalan Gajayana No. 50 Malang, HP. 085204931043 \\ email: ahrizfit@gmail.com
}

\begin{abstract}
The way of understanding to the mutasyabihat attributes of God, often become an object of discussion or even the reasons to mislead another Muslims. This happens since the past until today. The Effort to introduce more tolerant methods are needed to enable people aqidah and to maintain Islamic brotherhood. Shaykh Abdul Qadir al-Jilani was the leader that was recognized by scholars across schools of thought among Muslims. He was also known by Indonesian Muslims. So that the ideas of his thinking should be spread, like the methods to understand the mutasyabihat attributes of God. In understanding the mutasyabihat attributes of God, al-Jilani would prefer to use tafwidh method. But he did not directly assume misguiding people who disagreed with him. He only revealed that misguiding people in understanding the attributes of God are, first; people who personified God like creatures (such as Syi'ah ghaliyah); second; people who denied the attributes of God, although they reasoned to clean Him (such as Jahmiyah).
\end{abstract}

Cara memahami terhadap sifat-sifat Allah yang mutasyabihat, seringkali menjadi bahan diskusi bahkan alasan untuk menyesatkan di antara kaum muslim. Hal tersebut terjadi sejak dulu hingga sekarang. Upaya mengenalkan metode pemahaman yang lebih bersifat toleran diperlukan supaya aqidah umat tetap terjaga dan ukhwuah di antara mereka pun tetap terpelihara. Syaikh Abdul Qadir al-Jilani adalah tokoh yang diakui oleh para ulama lintas madzhab dan kelompok-kelompok yang ada di antara umat Islam. Ia pun dikenal luas oleh umat Islam Indonesia. Sehingga penyebaran ide-ide pemikirannya 
layak dilakukan, misalnya terkait metode memahami sifat-sifat Allah yang mutasyabihat. Dalam memahami sifat-sifat Allah yang mutasyabihat, Syaikh Abdul Qadir al-Jilani lebih memilih menggunakan metode tafwidh. Namun ia tidak otomatis menganggap sesat orang yang berbeda pendapat dengannya tentang pemilihan metode tersebut. Ia hanya mengungkapkan bahwa yang sesat dalam memahami sifat-sifat Allah adalah pertama, mereka yang mempersonifikasikan Allah seperti makhluk (seperti kelompok syi'ah ghaliyah); kedua, mereka yang mengingkari sifat-sifat Allah, meskipun dengan alasan untuk mensucikan-Nya (seperti kelompok Jahmiyah).

Key words: Shaikh Abdul Qadir al Jilani, the nature of God, mutasyabihat

\section{Pendahuluan}

Salah satu area dalam studi Islam yang sering menjadi bahan diskusi bahkan berujung saling menyesatkan di antara umat Islam adalah tema pemahaman terhadap sifat-sifat Allah yang bersifat mutasyabihat (maknanya tidak jelas). Hal tersebut terjadi sejak dulu hingga sekarang. Karenanya upayaupaya untuk menjernihkan masalah ini masih perlu terus diupayakan sehingga kaum muslim mendapatkan pemahaman yang tepat dan ukhuwah di antara mereka pun tumbuh subur.

Syaikh Abdul Qadir al Jilani adalah salah seorang tokoh ulama yang sangat dikenal luas oleh umat Islam di seluruh dunia, termasuk Indonesia. Ia dikenal sebagai pemimpin para wali, sehingga seringkali dalam acara keagamaan, dibacakan manaqib (riwayat hidup dan keutamaannya) dan al Fatihah yang dihadiahkan kepadanya.

Ketokohannya pun diakui oleh para ulama lintas madzhab dan umat Islam dari berbagai kelompok. Namun sayangnya, pada umumnya kaum muslim mengenalnya hanya sebatas biografi dan karomahnya, tidak lebih dari itu. Bagaimana konsep berpikirnya, apa yang ia lakukan dalam upaya dakwah fi sabilillah masing jarang diketahui oleh banyak orang. Oleh karena itu mengenal dan mendalami pemikirannya menjadi sesuatu yang sangat berharga. Tulisan ini ingin mengungkap metode yang dilakukan oleh Syaikh Abdul Qadir al Jilani dalam memahami sifat-sifat Allah yang mutasyabihat tersebut, kemudian membandingkannya dengan pandangan para ulama. Harapannya, bisa ditarik suatu kesimpulan terkait metode Syaikh Abdul Qadir al Jilani dalam memahami sifat-sifat Allah tersebut, sehingga bisa dijadikan sebagai contoh dan alternatif untuk memecahkan persoalan rusaknya ukhuwah yang disebabkan oleh perdebatan di seputar sifat-sifat Allah tersebut. 


\section{Sifat-sifat Allah}

Allah swt mempunyai sifat-sifat yang sempurna yang harus diimani oleh umat Islam. Sifat-sifat tersebut tercantum di dalam ayat-ayat al Qur'an dan hadits. Di antara ayat al Qur'an ada yang muhkam (maknanya jelas), dan ada juga yang mutasyabihat (yang maknanya samar). Contoh ayat muhkam yang berkaitan dengan sifat-sifat Allah adalah:

Tidak ada yang serupa dengan-Nya (QS Asyura:11).

Katakanlah: Allah itu Maha Esa. Allah itu tempat bergantung. (Dia) tidak beranak dan tidak diperanakkan. Dan tidak satupun yang sesuatupun yang menyamai-Nya (al Ikhlas :4)

Ayat-ayat ini sangat jelas dan terang maknanya, sehingga menjadi ayat muhkam.

Sedangkan contoh ayat/hadits mutasyabihat yang terkait sifat Allah adalah:

(Yaitu) Tuhan Yang Maha Pemurah, Yang bersemayam di atas <Arsy.(Q.S. Thaha: 5)

Dan datanglah Tuhanmu.... (Q.S. al Fajr: 22)

Semua yang ada di bumi itu akan binasa. Dan tetap kekal Dzat Tuhanmu yang mempunyai kebesaran dan kemuliaan.(Q.S. ar Rahman: 26-27)

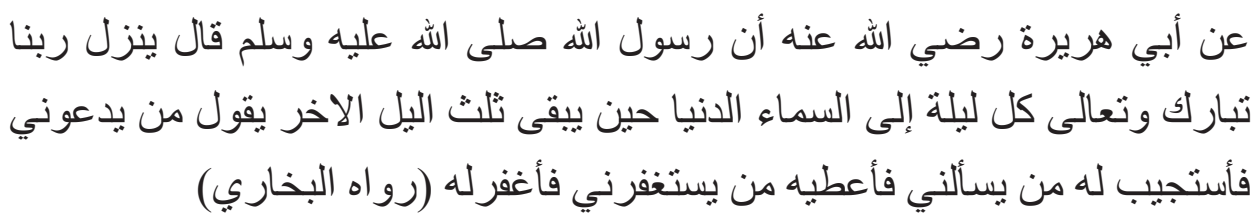

Dari Abu Hurairah ra, bahwa Rasulullah saw bersabda, "Pada setiap malam Tuhan swt selalu turun ke langit dunia ketika waktu tinggal sepertiga malam yang terakhir. Tuhan berfirman,'Siapa yang akan berdoa kepada-Ku, Aku pasti akan mengabulkannya. Siapa yang akan memohon kepada-Ku, Aku pasti memberinya. Dan siapa yang akan memohon ampunan kepada-Ku, Aku pasti mengampuninya."” (HR. al Bukhari: 1077).

\section{Metode Syaikh Abdul Qadir al-Jilani}

Di dalam memahami sifat-sifat Allah (yang mutasyabihat), Syaikh Abdul Qadir al Jilani lebih memilih untuk memutlakkan sifat Allah tanpa melakukan ta'wil. Syaikh Abdul Qadir al Jilani berkata, "Dan seyogyanya memutlakkan sifat istiwa' tanpa melakukan ta'wil. Kalimat istiwa' adz-dzaati 'ala al'arsy tidak bermakna al qu'ud (duduk) wa al mumasah (menempel) sebagaimana pendapat kelompok Mujassimah dan Karomiyyah, juga tidak berarti al 'uluwwi wa ar rif'ah sebagaimana pendapat kelompok al Asy-'ariy, serta tidak bermakna al 
istila' wa al gholabah sebagaimana pendapat kelompok Mu'tazilah". Al Jilani menggunakan hadits riwayat dari Ummi Salamah, istri Nabi Muhammad saw, ketika ditanya tentang firman Allah," Ar Rahmanu 'ala al'arsyi istawa", beliau menjawab:"Al Kayfu ghoiru ma'qulin ("bagaimana" tidak masuk akal dinyatakan pada Allah), wa al istiwa'u ghoiru majhulin (dan istiwa itu telah jelas penyebutannya dalam al Qur'an), wa al iqrooru bihi waajibun (dan menetapkan istiwa' bagi Allah hukumnya wajib), wa al juhdu bihi kufrun (dan tidak mengakui istiwa' bagi Allah, hukumnya kafir)". Ia juga mengatakan bahwa para shahabat dan tabi'in juga memutlakkan sifat-sifat Allah, tanpa melakukan ta'wil. (al Jilani, 2007: 124).

Al Jilani berkata:

"Istiwa' merupakan salah satu sifat Allah sebagaimana telah aku paparkan sebelumnya. Allah telah menetapkannya dan menguatkannya dengan tujuh ayat di dalam kitab-Nya dan sunnah. Istiwa' adalah sifat yang lazim dan pantas bagi Allah seperti al-yad, al-wajhu, al'ain, as-sam'u, al-bashar, al-hayat, al-qudrah, Khaliq, Raziq, Muhyi dan Mumit. Kita tidak mengeluarkannya dari Kitab dan Sunnah. Kita membaca keduanya dan mengimani apa-apa yang terdapat di dalamnya. Kita menyerahkan kaifiyyah tentang sifat kepada Allah 'Azza wa Jalla, sebagaimana pendapat Sufyan bin 'Uyainah rahimahullah: 'Sebagaimana Allah mensifati diri-Nya di dalam kitab-Nya'.

Maka tafsirnya adalah bacaannya. Tidak ada tafsir selainnya. Dan kita tidak dituntut selain hal tersebut, karena hal tersebut merupakan sesuatu yang ghaib, yang tidak bisa dijangkau oleh akal. Kita memohon ampunan kepada Allah dan kita berlindung dari mengatakan tentang sifat Allah dengan sesuatu yang tidak disampaikan oleh Allah atau rasul-Nya alaihish sholatu was salam."(al Jilani, 2007: 125).

Meskipun ia tidak setuju penggunaan ta'wil dalam memahami sifat Allah, namun ia tidak menjadikan kelompok Asy'ari, salah satu pengguna ta'wil, sebagai kelompok sesat. Hal ini menunjukkan bahwa Syaikh Abdul Qadir al Jilani tidak menjadikan penggunaan ta'wil sebagai kriteria sesat. Atau, setidaknya tidak menjadikan ta'wil yang dilakukan oleh kelompok Asy'ari sebagai kriteria sesat.

Adapun yang dijadikan Syaikh Abdul Qadir al Jilani sebagai kriteria sesat dalam hal pemahaman terhadap sifat-sifat Allah ini adalah pertama, menyerupakan Allah dengan makhluk; dan kedua, mengingkari sifat-sifat Allah (al Jilani, 2007: 124). Kelompok yang menyerupakan Allah dengan makhluk, biasanya mereka mengambil teks secara literal, kemudian menisbatkan wajah, tangan dan tertawa Allah seperti wajah, tangan dan tertawa manusia. Mereka adalah orang-orang yang menyerupakan (musyabbihah) dan mempersonifikasikan 
(mujassimah) Allah seperti makhluk. Syaikh Abdul Qadir al Jilani memberi contoh kelompok yang sering mempersonifikasikan Allah adalah kelompok Syi'ah Ghaliyyah.

Sedangkan kelompok yang kedua, yaitu yang mengingkari sifat-sifat Allah, seperti kelompok Jahmiyyah. Menurut mereka, Allah tidak mendengar dan tidak melihat. Karena, menurut mereka, mendengar dan melihat dilakukan dengan anggota tubuh. Sedangkan anggota tubuh harus di-nafi-kan dari Allah. Dengan demikian, mereka sebenarnya telah membuang sifat-sifat Allah dengan cara pura-pura mensucikan-Nya.

\section{Metode memahami sifat-sifat Allah}

Ada tiga metodologi yang digunakan oleh para ulama dalam memahami ayat-ayat dan hadits tentang sifat, yaitu tafwidh, itsbat dan ta'wil. Mayoritas ulama salaf dalam memahami ayat-ayat dan hadits tentang sifat Allah meggunakan metodologi tafwidh, yaitu tidak melakukan penafsiran apapun terhadap teks-teks tersebut, namun mencukupkan diri dengan penetapan sifat-sifat yang telah Allah tetapkan bagi Dzat-Nya, serta mensucikan Allah dari segala kekurangan dan penyerupaan terhadap hal-hal yang baru. Hal tersebut dilakukan dengan cara mengikuti metode ta'wil ijmali terhadap teks-teks tersebut dan menyerahkan pengetahuan maksud yang sebenarnya kepada Allah Subhanahu wa Ta'ala (al Buthi, 1997: 138). Biasanya mereka menggunakan bahasa "tidak tenggelam", "tidak menafsirkan", "diam terhadap sifat-sifat tersebut" dan "bacaannya adalah tafsirnya" (al Qaradhawi, 2009: 80-82).

Mayoritas ulama salaf dengan mengikuti metodologi tafwidh atau ta'wil ijmali, tidak mengartikan kata istiwa' dalam ayat di atas dengan bersemayam dan bertempat di 'Arasy. Dan tidak pula mengartikan datang dan turunnya Tuhan dalam ayat dan hadits tersebut dengan datang atau turun seperti halnya makhluk yang berpindah dan bergerak dari suatu tempat ke tempat yang lain. Ulama salaf berpandangan bahwa kata istiwa', datang dan turun dalam ayatayat tersebut memiliki makna-makna tersendiri yang hanya diketahui oleh Allah dan tidak mengandung penyerupaan sifat-sifat Allah dengan sifat-sifat makhluk-Nya (al Harari, 2007: 122).

Al Lalika'i meriwayatkan dari Muhammad bin al Hasan, sahabat Abu Hanifah, dia berkata,"Seluruh ahli fikih yang ada di timur dan barat sepakat tentang kewajiban beriman kepada al Qur'an dan hadits-hadits shahih tentang sifat Allah, tanpa harus menafsirkan, menggambarkan dan menyerupakan. Barangsiapa yang melakukan penafsiran, dia telah keluar dari ajaran Nabi dan 
jamaah. Sebenarnya, mereka tidak memberikan penyifatan dan melakukan penafsiran, tetapi memberikan fatwa dari al Qur'an dan as Sunnah untuk kemudian diam-dari fatwa tersebut (al Qaradhawi, 2009: 80).

Hasan al-Banna berkata,"Adapun ulama salaf ridhwanullah 'alaihim mengatakan:'Kita wajib beriman terhadap ayat-ayat dan hadits-hadits seperti apa adanya, dan menyerahkan maksudnya pada kehendak Allah.' Mereka menetapkan sifat al Yad, al 'Ain, al Istiwa', adh Dhahk, at Ta'ajjub dan seterusnya (untuk Allah). Semua ini memiliki makna yang tanpa bisa kita kenali, dan kita serahkan kepada Allah untuk mengetahui persisnya." (Aziz, 2005: 85-86, 90).

Al-Shaukani (w. $1250 \mathrm{H}$ ) juga mengikuti madzhab salaf yang berpendapat bahwa sifat-sifat Allah yang ada dalam al Qur'an dan hadits yang shahih harus diterima apa adanya tanpa takwil. Ketika menjelaskan ayat tentang Allah bersemayam di atas arsy (QS al A'raf ayat 54), al Shaukani berkata,"Sesungguhnya para ulama telah berbeda pendapat tentang makna ayat ini sehingga terdapat empat belas pendapat, yang paling benar dan paling dekat dengan yang seharusnya adalah pendapat salaf, yaitu Allah istiwa' tanpa diketahui caranya, sesuai dengan yang patut bagi-Nya serta dan dengan menafikan yang tidak patut bagi-Nya." (Zainuddin, 2009: 67).

Ibnu Qudamah al Maqdisy di dalam kitabnya, Lum'atul I'tiqad, mengatakan bahwa semua sifat ar Rahman yang ada di dalam al Qur'an dan hadits shahih wajib diimani dan diterima serta tidak diperbolehkan mengetahui maknanya dengan menolaknya, menakwilkannya, menyerupakannya dan mempersonifikasikannya. Sifat-sifat tersebut wajib kita tetapkan secara lafadz, dan tidak mencari-cari maknanya. Kita kembalikan pengetahuan tentangnya kepada yang mengucapkannya. Tindakan seperti itu sesuai dengan apa yang dilakukan oleh ar-rasikhina fil 'ilmi yang mendapat pujian dari Allah (al 'Utsaimin, 1992: 31).

Ibnu Qudamah juga mencuplik pandangan Imam Abu Abdillah Ahmad bin Muhammad bin Hambal radliyallahu' anhu tentang sabda Nabi Muhammad saw: 'Sesungguhnya Allah turun ke langit bumi', 'Sesungguhnya Allah akan dilihat di hari kiamat', dan hadits-hadits lain yang serupa dengannya. Imam Ahmad menjawab:

"Kami beriman dan membenarkannya, tidak ada cara dan tidak ada makna. Kami tidak menolaknya sedikitpun. Kami yakin bahwa sesuatu yang dibawa Rasul pasti benar. Kami tidak menolak apa yang dibawa Nabi saw dan kami tidak menyifati Allah melebihi apa yang Allah telah memberi sifat pada diri-Nya tanpa batasan. Tidak ada sesuatu pun yang menyerupai Allah. 
Dan Dia Maha Mendengar dan Maha Mengetahui. (Q.S. asy Syura: 11).” (al 'Utsaimin, 1992: 35).

Ketika membahas tentang ayat-ayat sifat yang mutasyabihat, dalam al Itqan, as Suyuthi berkata,"Jumhur Ahlu Sunnah-di antaranya kaum salaf-mdan ahli hadits berpendapat untuk mengimani ayat-ayat sifat dan menyerahkan maknanya kepada Allah. Dengan tetap menyucikan Allah, ayat-ayat tersebut tidak boleh ditafsirkan. Sebagian ahlu sunnah ada yang berpendapat untuk menakwil dengan sifat yang layak bagi Allah. Pendapat ini adalah pendapat kaum khalaf. Imam al Haramain pernah berpendapat seperti ini, tetapi dia meralat pendapatnya tersebut.

Ibnu Shalah berkata,'Pendapat inilah yang dilakukan oleh generasi pertama umat. Dan dengan cara inilah para ahli fikih berpendapat. Juga pendapat ini, adalah pendapat para ahli hadits. Tidak ada ahli kalam yang menolak pendapat seperti ini.'

Pendapat di atas dikomentari oleh Syaikh Mar'i dalam Aqawil ats Tsiqat,"Saya berpendapat bahwa pendapat di atas adalah pendapat yang paling tepat. Kita bisa mendapatkan setiap golongan yang melakukan takwil akan menyalahkan golongan yang lain. Mereka membuat argumentasi bahwa pendapat merekalah yang paling benar. Mereka meyakini bahwa golongan merekalah yang benar sedangkan golongan yang lain adalah salah. Hal tersebut sangat jelas terlihat ketika kita membaca pendapat-pendapat para ahli kalam dan tasawuf (al Qaradhawi, 2009: 56).

Itulah metodologi tafwidh yang digunakan oleh mayoritas ulama salaf, yaitu tidak mengartikan sifat-sifat Allah, menjauhi penafsirannya, dan menyerahkan maknanya kepada Allah. Dengan kata lain, Allah yang lebih tahu dengan arti ayat-ayat sifat tersebut. Mereka tidak menafsirkan ayat-ayat sifat Allah dengan tetap berpegang bahwa Allah adalah Maha Suci dari segala keserupaan dengan makhluk-Nya (al Qaradhawi, 2009: 46, 52).

Berbeda dengan metodologi tafwidh, adalah metodologi itsbat. Yaitu membiarkan sifat-sifat itu dalam arti literal dengan meniadakan cara dan penyerupaan. Metodologi ini dipopulerkan oleh Ibnu Taimiyyah dan madrasahnya (al Qaradhawi, 2009: 46-47).

Dalam karyanya yang berjudul "Shaid Al-Khathir," seorang ahli fikih, sejarawan, dai, kritikus dan pembaru, yaitu Ibnul Jauzi (w. 597 H), mendorong tentang pentingnya itsbat bagi masyarakat awam. Dalam pembahasan yang panjang, dia telah menjelaskan faedah hal tersebut bagi iman dan akhlak (al 
Qaradhawi, 2009: 203).

Sedangkan mayoritas ulama khalaf memahami ayat dan hadits tentang sifat Allah menggunakan metodologi ta'wil yaitu mengalihkan pengertian teks-teks yang mutasyabihat dari makna-makna literalnya dan meletakkan maksud-maksudnya dalam satu bingkai pengertian yang sejalan dan seiring dengan teks-teks lain yang muhkamat yang memastikan kesucian Allah dari arah, tempat dan anggota tubuh seperti makhluk-Nya. Oleh karena itu, mereka menafsirkan istiwa' dengan kekuasaan Allah, menafsirkan tangan Allah dengan kekuatan dan kedermawanan, menafsirkan 'ain (mata) dengan pertolongan (inayah) dan pemeliharaan (ri'ayah), menafsirkan dua jari-jari dalam hadits "Bayi seorang mukmin berada di antara dua jari-jari Tuhan" dengan kehendak (Iradah) dan kekuasaan (Qudrah) Allah dan lain sebagainya (al Buthi, 1997: 140).

Abu al Faraj bin Al Jauzi al Hanbali dalam kitabnya "Daf'u Syubhat atTasybih" mengatakan,"Allah berfirman :

Dan tetap kekal wajah Tuhanmu

Ahli tafsir menafsirkan, bahwa maksudnya adalah 'Dan tetap kekallah Tuhanmu'. Begitu juga dalam ayat,

Mereka menghendaki wajah-Nya (al An'am: 52)

Ahli tafsir menafsirkannya dengan,'Mereka menghendaki-Nya'.

Adh Dhahak dan Abu Ubaidah menafsirkan ayat,'Tiap-tiap sesuatu pasti binasa kecuali (wajah) Allah' (al Qashash: 88) dengan 'kecuali Allah'

Di awal buku tersebut, Ibnu al Jauzi menolak orang-orang yang mengatakan,"Sesungguhnya mengambil zhahir ayat-ayat dan hadits tadi adalah madzhab ulama salaf." Kesimpulan pandangan beliau, bahwa mengambil zhahir ayat berarti memberi bentuk organ tubuh, dan begitu seterusnya. Namun madzhab salaf tidaklah mengambil zhahirnya saja secara mutlak, tapi secara umum, mereka tidak berusaha untuk membahas dan mencari tahu tentangnya (Aziz, 2005: 91).

Apabila diamati dengan seksama, sebenarnya antara pendapat salaf (methode tafwidh) dengan pendapat khalaf (metode ta'wil) memiliki kesamaan, yaitu (al Qaradhawi, 2006: 38):

Pertama, sama-sama mensucikan Allah dari segala keserupaan dengan makhluk-Nya. Allah Subhanahu wa Ta'ala berfirman: Tidak ada sesuatu pun yang serupa dengan Dia, dan Dia-lah Yang Maha Mendengar lagi Maha Melihat. (QS. asy Syura: 11)

Ayat ini menegaskan kesucian Allah yang bersifat mutlak dari menyerupai 
apapun, sehingga ayat-ayat dan hadits-hadits lain yang mutasyabihat dan mengesankan bahwa Allah menyerupai makhluk-Nya harus dikembalikan maksudnya terhadap ayat ini, karena ayat ini kedudukannya muhkamat.

Kedua, mereka sepakat bahwa arti literal lafazh-lafazh tersebut bukanlah arti sebenarnya. Ini berkaitan dengan kesepakatan mereka untuk menafikan keserupaan Allah.

Ketiga, kedua madzhab sepakat bahwa lafazh-lafazh tersebut digunakan tiada lain untuk menjelaskan hal yang ada di dalam hati atau yang ada di bawah intuisi dan ada hubungannya dengan ahli bahasa. Meskipun sangat luas, hakekat bahasa tidak akan bisa diketahui artinya oleh orang yang tidak mengetahuinya. Dan hakekat yang berkaitan dengan Dzat Allah berkaitan dengan hal ini. Bahasa sangat terbatas untuk menjelaskan tentang hakekat tersebut. Dengan demikian, membatasi arti dari bahasa tersebut adalah sebuah penyesatan.

DR. Yusuf al Qaradhawi mengatakan bahwa polemik di antara dua manhaj atau dua madzhab tidak harus mengafirkan salah satu di antara keduanya. Dengan kata lain, menghukumi bahwa mereka telah melakukan jenis kekufuran terbesar yang mengakibatkan keluar dari agama Islam. Padahal, saling mengafirkan dan mengeluarkan mereka dari agama Islam tidak bisa diterima oleh hati dan akal orang yang berilmu. Karena mereka seluruhnya beriman kepada Tuhan, rasul, kitab suci, manhaj dan kiblat yang satu.

Menurutnya, polemik dalam permasalahan ini juga tidak perlu menyebabkan untuk menuduh dosa, fasik, dan bid'ah. Hal yang paling jauh, polemik yang terjadi adalah polemik antara yang benar dan yang keliru, atau yang benar dan yang lebih benar.

Bagaimana mungkin seorang ilmuwan yang mumpuni berani untuk memfasikkan, menuduh dosa atau membid'ahkan ulama umat. Padahal mereka-lah yang memikul syari'at, membela akidah dan melawan musuh-musuh dakwah. Sepanjang hayatnya, mereka hidup sebagai da'i, pembaru, ulama dan pelaksana ajaran Islam. Seperti al Baqillani, al Isfirayini, al Maturidi, al Ghazali, ar Razi, Ibnu Abdissalam, Ibnu al Id, ar Rafi'i, an Nawawi, Ibnul Hammam, az Zarkasyi, al Iraqi, Ibnu Hajar, as Suyuthi, dan orang-orang mumpuni lainnya yang menguasai ilmu akidah serta syari'at.

Ketika melakukan takwil, mereka tidak keluar dari kaidah-kaidah bahasa Arab. Sebelum mereka ada para sahabat yang juga melakukan takwil, tafwidh, dan itsbat. Seperti Ibnu Mas'ud, Ibnu 'Abbas, dan lain-lain (al Qaradhawi, 2006: 222-223). 
Ibnu Taymiyyah dan Ibnul Qoyyim juga berpendapat untuk tidak menuduh dosa, memfasikkan (fasik dalam ta'wil), atau menyesatkan orangorang yang melakukan ta'wil. Menurut Ibnu Taymiyyah, yang menjadi polemik dan ditentang oleh kaum salaf adalah ta'wil kelompok jahmiyyah dan pengetahuan manusia yang bisa mengetahui cara ayat-ayat sifat tersebut (al Qaradhawi, 2006: 43, 223).

Imam al Khathabi dalam Ma'alim as Sunannya, mengatakan bahwa orang yang melakukan ta'wil tidak keluar dari agama, meskipun ta'wilnya salah. Demikian juga menurut Imam al Ghazali, kesalahan dalam melakukan ta'wil tidak menyebabkan pada kekafiran, karena masih terjaga di bawah lindungan kalimat syahadat. Nash menetapkan bahwa yang menyebabkan seseorang menjadi kafir adalah ketika dia mendustakan Rasulullah shollallahu 'alaihi wa sallam. Dan orang yang salah dalam melakukan ta'wil bukanlah orang yang mendustakan Rasulullah (al Ghazali, 2008: 306). Dr. Yusuf al Qardlawi mengatakan, mereka tidak mengingkari hadits shahih. Akan tetapi penerimaan mereka ini wujud dalam bentuk penakwilan hadits disesuaikan dengan cara-cara ekspresi bahasa Arab, termasuk analogi, majaz, sindiran, perumpamaan, dan lainnya. Apakah penakwilan semacam ini benar atau tidak, ini sudah merupakan masalah tersendiri yang tidak ada kaitannya lagi dengan persoalan penetapan masalah aqidah melalui hadits. Bahkan pendukung pendapat ini mengatakan dengan tegas:"Saya menerima hadits itu dan mengakui juga konsekuensinya. Akan pengertian hadits ini bagi saya ialah begini dan begitu." (al Qaradhawi, 1997: 121).

Menurut Imam Ghazali, sosok manusia yang paling bersih dan jauh dari ranah ta'wil adalah Imam Ahmad Ibn Hambal-semoga kasih Allah selalu terlimpah untuknya. Namun, ternyata Imam Hambal terpaksa melakukan takwil. Menurut tokoh-tokoh terkemuka madzhab Hambali, sebagaimana dikutip oleh Imam Ghazali, Imam Ahmad Ibn Hanbal hanya melakukan dan mengemukakan ta'wil atas 3 hadits saja, yaitu (al Ghazali, 2003: 25-26):

1. Sabda (bahwa)"Hajar Aswad merupakan tangan kanan Allah di muka bumi." (H.R. al Hakim).

2. Sabda (bahwa) "Hati seorang mukmin berada di antara dua jari dari beberapa jari-jari Allah Yang Maha Pengasih)." (H.R. Muslim).

3. Sabda (bahwa) "Sesungguhnya aku menemukan Dzat (nafs) Sang Maha Pengasih berada di sebelah Yaman." (H.R. Ahmad)

Hasan al Banna berkata,"Saya melihat Imam an Nawawi memiliki pendapat yang mampu mendekatkan jarak khilaf antar kedua pendapat ini, 
sehingga memungkinkan kita untuk tidak terus berdebat dan bertentangan. Terlebih mereka telah memberi batasan dirinya bahwa menakwil seperti ini boleh selama tidak bertentangan dengan kaidah-kaidah agama.

Imam Ar-Razi dalam kitabnya 'Asas at-Taqdis berkata:

"Ketika kita memperbolehkan penakwilan, kita harus siap menyibukkan diri secara sukarela merinci beberapa penakwilan yang dimaksudkan. Jika kita memilih untuk tidak boleh menakwilkan, kita menyerahkan pengetahuan ini kembali kepada Allah. Ini adalah kaidah umum yang perlu menjadi rujukan pada setiap ayat-ayat dan hadits-hadits mutasyabihat. Hanya dari Allah kita berharap pertolongan.” (Aziz, 2005: 97).

\section{Simpulan}

Dalam memahami sifat-sifat Allah yang bersifat mutasyabihat, Syaikh Abdul Qadir al Jilani menggunakan metode tafwidz, yaitu menyerahkan makna sifat-sifat tersebut kepada Allah swt. Namun demikian, ia tidak menganggap sesat orang yang menggunakan metode ta'wil, selama tidak melanggar aqidah. Hal tersebut terbukti dengan sikapnya yang tidak menganggap sesat kelompok asy'ari. Sedangkan kelompok-kelompok yang memahami sifat-sifat Allah dengan cara yang bertentangan dengan aqidah, sebagaimana dicontohkan di atas yaitu kelompok Syi'ah Ghaliyah dan kelompok Jahmiyah dianggapnya sebagai kelompok sesat.

Sikap Syaikh Abdul Qadir al Jilani tersebut ternyata sama dengan apa yang dilakukan oleh para ulama. Sikap tersebut, yaitu tidak mudah menganggap sesat kelompok lain yang berbeda pendapat dengan kita, perlu dipupuk di tengah-tengah umat. Bila sikap tersebut dipahami secara menyeluruh oleh umat Islam, diharapkan akidah umat bisa terjaga dan ukhuwah di antara mereka pun tetap subur.

\section{Daftar Pustaka}

Abdul Aziz, Jum'ah Amin, 2005, Pemikiran Hasan Al-Banna dalam Akidah $\mathcal{E}$ Hadits, Terjemahan oleh Shofiyullah Mukhlas, Jakarta: Pustaka AlKautsar.

Al-'Utsaimin, Muhammad Shalih, 1992, Syarh Lum'atul I'tiqad, Riyadl: Maktabah Thabariyyah.

Al-Buthi, Muhammad Sa'id Ramadhan, 1997, Kubra al-Yaqiniyyat al-Kauniyyah, Damaskus: Dar al-Fikr. 
Al-Ghazali, 2003, Etika Berakidah, diterjemahkan dari Fasl at-Tafriqah, Yogyakarta: Pustaka Sufi.

Al-Ghazali, Imam, 2008, Al-Iqtishod fi al-I'tiqod, Cetakan Pertama, Beirut: Dar Al-Minhaj Lin-Nasyr wat Tauzi'.

Al-Jilani, Abdul Qadir, 2007, Al-Ghunyah li Tholibi Thoriqi al-Haqqi 'Azza wa Jalla, edisi Ketiga, Beirut: Dar al-Kutub al-'Ilmiyyah,.

Al-Qaradlawi, Yusuf, 1997, Fiqih Peradaban: Sunnah sebagai Paradigma Ilmu Pengetahuan, Terjemahan oleh Faizah Firdaus, Surabaya: Dunia Ilmu.

Yusuf al-Qaradhawi, 2006, Akidah Salaf dan Khalaf, penerjemah: Arif Munandar Riswanto, cet. I, Jakarta: Pustaka Al-Kautsar.

Al-Qaradlawi, Yusuf, 2009, Akidah Salaf dan Khalaf, cetakan Kedua, Terjemahan oleh Arif Munandar Riswanto, Jakarta: Pustaka Al-Kautsar.

Zainuddin, 2009, Al-Shaukaniy dan Kitab Nayl Al-Autar, Jakarta: Jurnal Islamia Vol. V no.1. 